\section{Acknowledgments}

We thank Frode Bergan for help with excavating the beaver and Inger Hanssen-Bauer for providing the weather data. The study was financially supported by Telemark University College. The experiments comply with the current Norwegian law, the country in which they were performed.

\section{Literature Cited}

Alterra. 1999. Alterra (IBN/DLO) P.O. Box 23. 6700 AA Wageningen. Netherlands.

Campbell, R. D. 2000. Territoriality in the European Beaver, Castor fiber. MSc thesis, School of Biological Sciences, University of East Anglia, Norwich, England.

Nolet, B. A., S. Broekhuizen, G. M. Dorrestein, and K. M. Rienks. 1997. Infectious diseases as main factors of mortality to beavers Castor fiber after translocation to the Netherlands. Journal of Zoology, London 241: 35-42.

Rosell, F., H. Parker, and N. B. Kile. 1996. Causes of mortality in beaver (Castor fiber \& canadensis). Fauna 49: 34-46 [In Norwegian with English summary].

van Nostrand, F. C., and A. B. Stephenson. 1964. Age determination for beavers by tooth development. Journal of Wildlife Management 28: 430-434.

Wilsson, L. 1971. Observations and experiments on the ethology of the European beaver (Castor fiber L.). Viltrevy 8: $1-266$.

Żurowski, W. 1992. Building activity of beavers. Acta Theriologica 37: 403-411.

Received 26 November 2002

Accepted 1 November 2004

\title{
Frequency of Tail Breakage of the Northern Watersnake, Nerodia sipedon sipedon
}

\author{
KenNeTH D. BoweN ${ }^{1,2}$ \\ ${ }^{1}$ Department of Biology, Central Michigan University, Mt. Pleasant, MI 48859 USA \\ ${ }^{2}$ Present Address: 709 Ringold Street, Boone, Iowa 50036 USA
}

Bowen, Kenneth D. 2004. Frequency of tail breakage in the Northern Watersnake, Nerodia sipedon sipedon. Canadian Field-Naturalist 118(3): 435-437.

I noted the frequency of broken tails of Northern Watersnakes, Nerodia sipedon sipedon, in the Beaver Archipelago of Northeastern Lake Michigan. Overall, $10 \%$ (22 of 220) of captured snakes had broken tails. This value is similar to published values for closely related snakes but is smaller than those reported for another Nerodia sipedon sipedon population. Unlike some previously published studies, the frequency of injured tails was not greater for females or lesser for first-year snakes. The mechanism behind the injury frequency observed here and the reason for differences between this and other studies are unknown.

Key Words: Beaver Archipelago, Nerodia sipedon sipedon, Northern Watersnake, tail breakage, Michigan.

The frequency of tail injuries in a lizard or snake population was at one time considered to be a useful index of the predation pressure on that population because tail autotomy and breakage (Mendelson 1992) are thought to be important defense mechanisms (reviewed in Arnold 1988). More recently, theoretical and empirical tests of this hypothesis have led to the assertion that loss or injury of the tail may instead be related to predator inefficiency or alternative sources of mortality and that careful investigation must be undertaken to determine the mechanism behind observed injury frequencies (Schoener 1979; Medel et al. 1988). While such data must indeed be interpreted with caution, reporting the frequency of tail injury in study populations can be useful when combined with demographic data (Arnold 1988), for example in forming hypotheses regarding sex or size-based differences in anti-predator mechanisms (Fitch 2003).

Several researchers have reported the frequency of tail injuries in populations of snakes. Fitch (1999) found that the frequency of tail breakage increased with the age/size of individuals in a Kansas population of Nerodia s. sipedon, the Northern Watersnake. More specif- ically, the frequency of female tail breakage ranged from 21.2 to $44.5 \%$, and the frequency of male tail breakage ranged from 6.5 to $25 \%$ in increasing body size categories. Willis et al. (1982) reported that female Eastern Garter Snakes (Thamnophis sirtalis) and Northern Ribbon Snakes (Thamnophis sauritus) had a higher incidence of tail loss than males (13\% versus $6 \%$, and $12 \%$ versus $7 \%$, respectively) and that tail loss was more prevalent in larger size classes. However, neither trend was statistically significant in populations of Butler's Garter Snake (Thamnophis butleri). Fitch (2003) found that tail breakage was more common for female $T$. sirtalis $(16.7 \%)$ than for males $(10.3 \%)$ and more common for large snakes $(13.7 \%)$ than for firstyear snakes $(2.42 \%)$. In general, females and larger snakes appear more likely to have broken tails.

I studied the frequency of broken tails of the Northern Watersnake in the Beaver Archipelago of northeastern Lake Michigan during the summers of 2000 and 2001. I captured snakes from Beaver Island $\left(45^{\circ} 41.26^{\prime} \mathrm{N}, 85^{\circ} 30.34^{\prime} \mathrm{W}\right)$, Garden Island $\left(45^{\circ} 48.28^{\prime} \mathrm{N}\right.$, $\left.85^{\circ} 29.41^{\prime} \mathrm{W}\right)$, High Island $\left(45^{\circ} 43.88^{\prime} \mathrm{N}, 85^{\circ} 39.54^{\prime} \mathrm{W}\right)$, and Hog Island $\left(45^{\circ} 48.39^{\prime} \mathrm{N}, 85^{\circ} 22.15^{\prime} \mathrm{W}\right)$. Upon cap- 
TABLE 1. Chi-square contingency table for comparison of the frequency of tail breakage among male, female, and first-year Nerodia sipedon sipedon in the Beaver Archipelago of Lake Michigan. The calculated $\chi^{2}$ was $0.23\left(\operatorname{critical} \chi^{2}=5.99\right.$, df $\left.=2\right)$.

\begin{tabular}{lcccr}
\hline \hline Class & $\begin{array}{c}\text { Number of } \\
\text { injured snakes }\end{array}$ & $\begin{array}{c}\text { Number of } \\
\text { uninjured snakes }\end{array}$ & Total & \% Injured \\
\hline Male & 7 & 55 & 62 & 11.3 \\
Female & 13 & 120 & 133 & 9.8 \\
First-year & 2 & 23 & 25 & 8.0 \\
Totals & 22 & 198 & 220 & 10.0 \\
\hline \hline
\end{tabular}

ture, I brought snakes to the laboratory where I then measured snout-vent length (SVL) and noted the tail condition and sex of each individual. I released all snakes at the point of capture as soon as possible after processing. I pooled snakes from all islands and calculated the overall percentage of snakes with tail breaks. I also compared the frequency of broken tails among males, females, and unsexed first-year snakes, and among three capture locations (Beaver Island Lake Michigan shoreline, Beaver Island interior lake, and Garden Island Lake Michigan shoreline) within sexes using Chi-square contingency table analysis. I hypothesized that females would have a higher frequency of tail breakage than males and that first-year snakes would have a lower frequency of tail breakage than both males and females.

Two hundred and twenty snakes were captured from the four islands. Beaver Island produced 153 snakes, Garden Island 55, High Island 1, and Hog Island 11 snakes. Captured snakes ranged in size from 149 to $860 \mathrm{~mm}$ SVL with a mean of $478.2 \mathrm{~mm}$ and a standard deviation of $164 \mathrm{~mm}$. In all, $10 \%$ (22) of the snakes had broken tails. There was no statistically significant difference in the frequency of tail breakage among males, females, and first-year snakes $\left(\chi^{2}=0.23\right.$, critical $\chi^{2}=5.99$, df $=2$; Table 1$)$. Within males, there was no statistically significant difference in the fre- quency of tail breakage among capture sites $\left(\chi^{2}=0.33\right.$, critical $\chi^{2}=5.99$, df $=2$; Table 2). However, females captured on the Lake Michigan shoreline of Garden Island had a higher frequency of tail breakage than those captured elsewhere $\left(\chi^{2}=8.9\right.$, critical $\chi^{2}=5.99$, df $=2$; Table 3 ).

My data do not closely match those of any previous studies. The overall frequency of tail breakage is similar to that reported by Willis et al. (1982). However, unlike the populations of $N$. s. sipedon and $T$. sirtalis studied by Fitch $(1999 ; 2003)$, and the populations of $T$. sirtalis and $T$. sauritus studied by Willis et al. (1982), the frequency of broken tails is not greater for females in the Beaver Archipelago overall (although it is greater if only Garden Island is considered). Furthermore, first-year snakes in the Beaver Archipelago do not appear to have a lower frequency of tail breakage than larger snakes. The T. butleri populations of Willis et al. (1982) appear to be similar to my snakes in the lack of common patterns of tail breakage. The sample size (287) for $T$. butleri in that study is similar to my own, while the sample sizes of the $T$. sirtalis, T. sauritus and N. s. sipedon studies are considerably larger. This suggests that the ability to detect patterns in the frequency of tail injuries in snake populations may be dependent upon sample size.

TABLE 2. Chi-square contingency table for comparison of the frequency of tail breakage of male Nerodia sipedon sipedon among capture sites in the Beaver Archipelago of Lake Michigan. The calculated $\chi^{2}$ was $0.33\left(\operatorname{critical} \chi^{2}=5.99\right.$, df =2).

\begin{tabular}{lcccc}
\hline \hline $\begin{array}{l}\text { Capture } \\
\text { site }\end{array}$ & $\begin{array}{c}\text { Number of } \\
\text { injured snakes }\end{array}$ & $\begin{array}{c}\text { Number of } \\
\text { uninjured snakes }\end{array}$ & Total & \% Injured \\
\hline Beaver Island Lake Michigan shoreline & 2 & 15 & 17 & 11.8 \\
Beaver Island interior lakes & 2 & 20 & 22 & 9.1 \\
Garden Island Lake Michigan shoreline & 3 & 18 & 21 & 14.3 \\
\cline { 2 - 5 } Totals & 7 & 53 & 60 & 11.7 \\
\hline \hline
\end{tabular}

TABLE 3. Chi-square contingency table for comparison of the frequency of tail breakage of female Nerodia sipedon sipedon among capture sites in the Beaver Archipelago of Lake Michigan. The calculated $\chi^{2}$ was $8.9\left(\operatorname{critical} \chi^{2}=5.99, \mathrm{df}=2\right)$.

\begin{tabular}{|c|c|c|c|c|}
\hline Capture site & $\begin{array}{l}\text { Number of } \\
\text { injured snakes }\end{array}$ & $\begin{array}{c}\text { Number of } \\
\text { uninjured snakes }\end{array}$ & Total & $\%$ Injured \\
\hline Beaver Island Lake Michigan shoreline & 4 & 60 & 64 & 6.2 \\
\hline Beaver Island interior lakes & 2 & 34 & 36 & 5.5 \\
\hline Garden Island Lake Michigan shoreline & 7 & 21 & 28 & 25.0 \\
\hline Totals & 13 & 115 & 128 & 10.1 \\
\hline
\end{tabular}


Fitch (2003) suggested that the frequency of tail breakage should be expected to vary among different study sites based on the presence of predators and availability of escape cover. Such factors may explain the differences in overall frequency of tail breakage between this and other studies and between islands in the Beaver Archipelago within females. Fitch (1999) also suggested that $N$. s. sipedon individuals with greater mass are more likely to have broken tails because they whirl repeatedly in an attempt to escape when grasped by a predator. Greater mass makes tail breakage more likely when this whirling motion is employed. The smaller mass of first-year snakes, the smaller mass of male N. s. sipedon in comparison to females of the same age (Fitch 1999), and the fact that broken tails may potentially damage the hemipenes of males all suggest that these groups should have lower frequencies of tail breakage than large snakes and females, respectively, regardless of locality. These patterns were not clear in this study or in the populations of $T$. butleri studied by Willis et al. (1982).

Sample size may be the critical factor in the discrepancy between studies. The two studies that did not show common patterns in tail breakage had relatively small sample sizes. A large sample size may be necessary for two reasons: (1) the patterns are real but the categorical nature of the data (break or no break) requires that large samples be collected for a pattern to be detectable, or (2) the patterns are not real but stem from the fact that any difference, no matter how small, can be statistically significant if the sample size is large enough (Johnson 1999). The general similarity of patterns of tail breakage across studies with large sample sizes suggests that the first reason may be the case. However, discrepancies among studies underscore the need for more research in this area. Researchers should continue to record and report the frequency of tail breakage in populations of lizards and snakes, but more carefully designed studies that attempt to determine the direct causes and consequences of tail breakage are needed (Medel et al. 1988). Until such studies are carried out, the meaning and utility of tail breakage data will remain speculative.

\section{Acknowledgements}

This research was done as part of a M.S. thesis at Central Michigan University. I thank my Thesis committee: James C. Gillingham, Michael J. Hamas, and David L. Clark. I also thank John W. Rowe for help and advice in the field and laboratory. E. S. Bowen, M. F. Haussmann, and two anonymous reviewers provided valuable comments on earlier drafts. Financial support was provided by the Central Michigan University Department of Biology, the Central Michigan University College of Graduate Studies, and the Central Michigan University Biological Station on Beaver Island. Animals were collected under MDNR Cultural and Scientific Collector's Permit CA 341 issued to J. C. Gillingham. The experimental protocol was approved by the Central Michigan University Institutional Animal Use and Care Committee (approval number 02-06).

\section{Literature Cited}

Arnold, E. N. 1988. Caudal autotomy as a defense. Pages 235273 in Biology of the Reptilia. Volume 16, Ecology B. Edited by C. Gans and R. B. Huey. Alan R. Liss Inc., New York.

Fitch, H. S. 1999. A Kansas snake community: composition and changes over 50 years. Krieger Publishing Company, Malabar, Florida xi +165 pages.

Fitch, H. S. 2003. Tail loss in Garter Snakes. Herpetological Review 34: 212-213.

Johnson, D. H. 1999. The insignificance of statistical significance testing. Journal of Wildife Management 63: 763772.

Medel, R. G., J. E. Jimenez, S. F. Fox, and F. M. Jaksic. 1988. Experimental evidence that high population frequencies of lizard tail autotomy indicate inefficient predation. Oikos 53: 321-324.

Mendelson, J. R. 1992. Frequency of tail breakage in Coniophanes fissidens (Serpentes: Colubridae). Herpetologica 48: 448-455.

Schoener, T. W. 1979. Inferring the properties of predation and other injury-producing agents from injury frequencies. Ecology 60: 1110-1115.

Willis, L., S. T. Threlkeld, and C. C. Carpenter. 1982. Tail loss patterns in Thamnophis (Reptilia: Colubridae) and the probable fate of injured individuals. Copeia 1982: 98-101.

Received 21 February 2003

Accepted 4 November 2004 